\title{
PENGARUH MODEL PEMBELAJARAN PROBLEM BASED LEARNING MENGGUNAKAN PETA KONSEP TERHADAP HASIL BELAJAR SISWA
}

\author{
Maghfirah HR dan Mara Bangun Harahap \\ Jurusan Fisika FMIPA Universitas Negeri Medan \\ Maghfirahhr2@gmail.com
}

\begin{abstract}
ABSTRAK
Penelitian ini bertujuan untuk mengetahui pengaruh model problem based learning menggunakan peta konsep terhadap hasil belajar siswa pada materi fluida statis di kelas XI semester II SMA Negeri 1 Tanjung Morawa T.P.2014/2015. Jenis penelitian ini adalah quasi eksperimen. Populasi dalam penelitian ini adalah seluruh siswa kelas XI SMA Negeri 1 Tanjung Morawa T.P. 2014/2015 dengan jumlah 5 kelas. Pengambilan sampel dilakukan dengan cara cluster random sampling dengan mengambil 2 kelas dari 4 kelas secara acak yaitu kelas $\mathrm{XI}^{4}$ sebagai kelas eksperimen dengan menggunakan model problem based learning dan kelas $\mathrm{XI}^{3}$ sebagai kelas kontrol menggunakan model pembelajaran konvensional. Kelas eksperimen dan kelas kontrol berjumlah 43 orang Berdasarkan hasil analisis data diperoleh nilai rata-rata hasil belajar siswa yang diberi perlakuan dengan model problem based learning menggunakan peta konsep 75,76 dan kelas kontrol yang menggunakan model pembelajaran konvensional 70,53. Selama proses pembelajaran menggunakan model problem based learning menggunakan peta konsep, nilai rata-rata aktivitas belajar siswa adalah 72,78 (Aktif).Dari hasil pengolahan data postes diperoleh bahwa ada pengaruh model problem based learning menggunakan peta konsep terhadap hasil belajar siswa pada materi fluida statis di kelas XI semester II SMA Negeri 1 Tanjung Morawa T.P.2014/2015.
\end{abstract}

Kata Kunci : Problem based learnig, peta konsep, hasil belajar

\begin{abstract}
This study aims to determine the effect of problem based learning models using concept maps to student learning outcomes in a static fluid material in the second semester class XI SMA Negeri 1 Tanjung Morawa TP2014/2015. This research is a quasi experimental. The population in this study were all students of class XI SMA Negeri 1 Tanjung Morawa TP 2014/2015 the number 5 grade. Sampling was done by cluster random sampling by taking two classes of fourth grade at random which XI4 class as a class experiment using a model of problem-based learning and classroom XI3 as grade control using conventional learning models. Experimental class and control class numbered 43 Based on the analysis of data obtained by the average value of student learning outcomes treated with problembased learning models using concept maps 75.76 and grade control using conventional learning models 70.53. During the learning process using a model of problem-based learning using concept maps, the average value of student learning activity was 72.78 (Active). From the data processing post-test showed that there is influence of problem based learning models using concept maps to student learning outcomes in a static fluid material in the second semester class XI SMA Negeri 1 Tanjung Morawa T.P. 2014 / 2015.
\end{abstract}

Keywords: Problem-based learnig, concept maps, learning outcomes 


\section{PENDAHULUAN}

Pendidikan merupakan salah satu hal terpenting bagi setiap bangsa. Tingkat kemajuan suatu bangsa dapat dilihat dari tingkat pendidikan masyarakatnya dengan kata lain tingkat pendidikan merupakan indikator maju mundurnya suatu bangsa.

Rendahnya pendidikan formal (sekolah) dewasa ini di akibatkan daya serap peserta didik hal ini tampak dari hasil belajar peserta didik yang senantiasa masih sangat memperihatinkan.

Dunia pendidikan mata pelajaran fisika adalah salah satu cabang IPA yang merupakan suatu ilmu pengetahuan yang mempelajari gejala-gejala alam dan interaksi di dalamnya serta dapat diterangkan dengan konsep-konsep sederhana. Pelajaran Fisika lebih menekankan pada pemberian langsung untuk meningkatkan kompetensi agar siswa mampu berpikir kritis dan sistematis dalam memahami konsep Fisika, sehinggasiswamemperoleh pemahaman yang benar tentang Fisika. Pemahaman yang benar akan pelajaran Fisika akan sangat berpengaruh terhadap hasil belajar siswa.

Penelitian sebelumnya didapat hasil nilai Ujian Akhir Nasional (UAN) terutama untuk pelajaran fisika, nilai yang di peroleh siswa sangat rendah seperti MAN 2 Medan, hasil UAN bidang studi fisika adalah 3,65. (Panggabean,2010).

Rendahnya tingkat pendidikan dapat disebabkan oleh berbagai faktor di antaranya faktor yang berasal dari dalam diri siswa dan dari luar diri siswa. Faktor yang berasal dari dalam diri siswa meliputi kemampuan, kesiapan, sikap, minat dan intelegensi. Faktor yang berasal dari luar siswa yaitu guru antara lain pemilihan strategi pembelajaran yang kurang tepat, kurang menarik dan terkesan sulit sehingga siswa lebih dahulu merasa jenuh sebelum mempelajarinya. (Turnip, 2010).

Adapun faktor lain yang mempengaruhi hasil belajar fisika yang rendah dapat disebabkan oleh kualitas mengajar guru yang kurang dapat mempengaruhi siswa untuk belajar. Selain itu, sering kali pelajaran fisika disajikan guru dalam bentuk persamaan matematik dan mengutamakan perhitungan dari pada penjelasan konsep fisikanya, sehingga siswa sering hanya dapat menghitung tetapi tidak mengerti konsep fisikanya. Hal inilah penyebab ketidakmampuan siswa untuk menerapkan konsepkonsep fisika dalam kehidupan seharihari dan akan mengurangi minat siswa untuk belajar siswa. (Panggabean,2010)

Hal ini juga terlihat dari obsevasi yang dilakukan di SMA Negeri 1 Tanjung Morawa, penulis menemukan masih rendahnya hasil belajar siswa terutama pada mata pelajaran fisika rata-rata dibawah Kriteria Ketuntasan Minimum (KKM) 70. Banyak siswa yang berpendapat bahwa belajar fisika itu membosankan, tidak menarik dan merupakan pelajaran yang sulit dipahami. Hasil data angket yang diberikan kepada semua siswa kelas XI, diperoleh 82,9\% menyatakan tidak menyukai pembelajaran fisika dan menganggap pelajaran fisika sulit dan kurang dimengerti. Menyatakan pelajaran fisika biasa saja $64,3 \%$ dan $22,8 \%$ menyatakan pelajaran fisika menarik dan menyenangkan dan nilai hasil belajar siswa rata-rata diatas KKM.

Salah satu upaya untuk mengatasi permasalahan di atas adalah dengan mengembangkan model pembelajaran yang efektif, yang melibatkan siswa secara aktif, memperhatikan kemampuan siswa dan menggunakan peta konsep dengan tepat. Sehubungan dengan masalah di atas, maka salah satu alternatif yang dapat digunakan untuk mengatasi permasalahan ini adalah dengan 
menggunakan model Problem Based Learning (PBL) menggunakan peta konsep.

(Mukhtar dkk, 2013) mengatakan bahwa belajar berbasis masalah adalah suatu pendekatan pembelajaran yang melibatkan siswa aktif secara optimal, memungkinkan siswa melakukan investigasi, pemecahan masalah yang mengintegrasikan keterampilan dan konsep dari berbagai konten area.

Menggunakan model ini diharapkan dapat meningkatkan rasa ingin tahu serta minat siswa sehingga dapat memotivasi siswa untuk lebih giat dalam belajar.

\section{METODE PENELITIAN}

Penelitian ini dilaksanakan di SMA Negeri 1 Tanjung Morawa yang beralamat di. Jalan Batang Kuis Pasar VIII No. 151 Kecamatan Tanjung Morawa, kabupaten Deli Serdang. Penelitian ini dilakukan dari bulan Januari-Juni 2015.

Populasi dalam penelitian ini adalah seluruh siswa kelas XI semester II SMA Negeri 1 Tanjung Morawa T.P. 2014/2015 yang berjumlah 4 kelas.

Sampel penelitian diambil menggunakan teknik (cluster random sampling), jumlah sampel sebanyak dua kelas. Kelas XI ${ }^{4}$ dijadikan sebagai kelas ekperimen yaitu kelas yang diajarkan dengan model pembelajaran problem based learning dan kelas $\mathrm{XI}^{3}$ dijadikan sebagai kelas kontrol yaitu kelas yang diajar dengan pembelajaran konvensional.

Jenis penelitian ini adalah kuasi eksperimen ini dengan desain $t w o$ group pretest-postest design seperti yang ditunjukkan pada Tabel 1 .

Tabel 1. Desain Penelitian tipe Two GroupPretest-Postest

\begin{tabular}{lccc}
\hline \multicolumn{1}{c}{ Kelas } & Prete & $\begin{array}{c}\text { Perlaku } \\
\text { an }\end{array}$ & Postes \\
& $S$ & $\mathrm{X}$ & $\mathrm{T}_{2}$ \\
\hline Eksperimen & $\mathrm{T}_{1}$ & $\mathrm{X}$ & $\mathrm{T}_{2}$ \\
\hline Kontrol & $\mathrm{T}_{1}$ & $\mathrm{Y}$ & $\mathrm{T}_{2}$ \\
\hline
\end{tabular}

Keterangan:

$\mathrm{T}_{1}=$ Pemberian tes awal (pre-tes)

$\mathrm{T}_{2}=$ Pemberian tes akhir (pos-tes)

$\mathrm{X}=$ Perlakuan dengan model problem based learning menggunakan peta konsep

$\mathrm{Y}=$ Perlakuan dengan model pembelajaran konvensional

Alat pengumpul data dalam penelitian ini adalah tes berbentuk uraian untuk mengetahui hasil belajar siswa pada ranah kognitif dan lembar observasi untuk mengetahui aktivitas siswa.

Uji hipotesis menggunakan uji $\mathrm{t}$ dengan membandingkan rata-rata skor hasil belajar yang dicapai baik kelas eksperimen maupun kelas kontrol. Data yang diperoleh ditabulasikan kemudian dicari rata-ratanya. Sebelum dilakukan penganalisisan data, terlebih dahulu ditentukan skor masing-masing kelompok sampel lalu dilakukan pengolahan data dengan langkahlangkah sebagai berikut:

a) Menghitung nilai rata-rata dan simpangan baku

b) Uji normalitas

c) Uji homogenitas

d) Uji kesamaan rata-rata pretes

Uji t satu pihak digunakan untuk mengetahui kesamaan kemampuan awal siswa pada kedua kelompok sampel. Hipotesis yang diuji berbentuk

$\mathrm{H}_{\mathrm{o}}: \mu_{1}=\mu_{2}$ : kelas eksperimen dan kelas kontrol mempunyai kemampuan awal yang sama.

$\mathrm{H}_{\mathrm{a}}: \mu_{1} \neq \mu_{2}$ : kelas eksperimen dan kelas kontrol mempunyai kemampuan awal yang berbeda.

e) Pengujian hipotesis

Uji t dua pihak juga digunakan untuk mengetahui perbedaan dari suatu perlakuan yaitu model pembelajaran problem based learning menggunakan peta konsepdan model pembelajaran konvensional terhadap hasil belajar siswa. Hipotesis yang diuji berbentuk: 


$$
\begin{aligned}
& \text { Ho: } \sqrt{?_{1}}=\sqrt{2} \\
& \mathrm{Ha}: \sqrt[?_{1}]{?_{2}}>\sqrt{2}
\end{aligned}
$$

Keterangan :

]$\left._{1}=\right]_{2}:$ Tidak ada perbedaan hasil belajar siswa akibat pengaruh model pembelajaran model pembelajaran problem based learning menggunakan peta konsep dengan pembelajaran konvensional.

]$\left._{1}>\right]_{2}:$ Ada perbedaan hasil belajar siswa akibat pengaruh model pembelajaran model pembelajaran problem based learning menggunakan peta konsep dengan pembelajaran konvensional.

\section{HASIL PENELITIAN DAN PEMBAHASAN}

\section{Hasil Penelitian}

Penelitian diawali dengan memberikan kedua kelas tes uji kemampuan awal (pretes) yang bertujuan untuk mengetahui apakah kemampuan awal siswa pada kedua kelas sama atau tidak. Hasil pretes kelas eksperimen memperoleh nilai rata-rata 42,39 dan nilai rata-rata kelas kontrol adalah 42,16. Setelah memperoleh data pretes siswa, maka dilakukan pengujian analisis data dengan menggunakan uji kesamaan rata-rata pretes dimana syaratnya data harus berdistribusi normal dan homogen. Hasil uji normalitas data pretes ditunjukkan pada Tabel 2 .

Tabel 2. Uji Normalitas Data Pretes

\begin{tabular}{|l|l|c|l|l|}
\hline No & \multicolumn{1}{|c|}{ Data } & Lhitung & Ltabel & $\begin{array}{l}\text { Kesim } \\
\text { pulan }\end{array}$ \\
\hline 1 & $\begin{array}{l}\text { Pretes } \\
\text { Kelas } \\
\text { Eksperimen }\end{array}$ & 0,079 & & 0,13 \\
\hline 2 & $\begin{array}{l}\text { Pretes } \\
\text { Kelas } \\
\text { Kontrol }\end{array}$ & 0,106 & $\begin{array}{l}\text { Norm } \\
\text { al }\end{array}$ \\
\hline
\end{tabular}

Tabel 2 menunjukkan bahwa Lhitung $<$ Ltabel baik kelas eksperimen dan kelas kontrol dengan $\alpha=0,05$, sehingga dapat disimpulkan bahwa data berdistribusi normal
Tabel 3.Uji Homogenitas Data Pretes

\begin{tabular}{|l|l|c|c|c|c|}
\hline No & \multicolumn{1}{|c|}{ Data } & $\begin{array}{l}\text { Vari } \\
\text { ans }\end{array}$ & $\begin{array}{r}\mathrm{F}_{\text {hitu }} \\
\text { ng }\end{array}$ & F $_{\text {tabel }}$ & $\begin{array}{c}\text { Kesimp } \\
\text { ulan }\end{array}$ \\
\hline 1 & $\begin{array}{l}\text { Pretes } \\
\text { Kelas } \\
\text { Eksperime } \\
\text { n }\end{array}$ & $\mathbf{6 2 , 7 2}$ & 1,1 & 1,7 & $\begin{array}{l}\text { Hom } \\
\text { ogen }\end{array}$ \\
\cline { 1 - 4 } 2 & $\begin{array}{l}\text { Pretes } \\
\text { Kelas } \\
\text { Kontrol }\end{array}$ & $\begin{array}{c}56,9 \\
0\end{array}$ & & & \\
\hline
\end{tabular}

Tabel 3 menunjukkan bahwa $\mathrm{F}_{\text {hitung }}<\mathrm{F}_{\text {tabel }}$ yaitu $1,1<1,7$ dengan $\mathrm{a}=$ 0,05, maka dapat disimpulkan bahwa data pretes kelas eksperimen memiliki varians yang sama dengan kelas kontrol (homogen).

\begin{tabular}{|c|c|c|c|c|c|}
\hline No & Data & $\begin{array}{l}\text { Nilai } \\
\text { Rata } \\
\text {-rata }\end{array}$ & $\begin{array}{c}\text { thitun } \\
\mathrm{g}\end{array}$ & $\mathrm{t}_{\text {tabel }}$ & $\begin{array}{l}\text { Kesim } \\
\text { pulan }\end{array}$ \\
\hline 1 & $\begin{array}{l}\text { Pretes } \\
\text { Kelas } \\
\text { Eksperime } \\
\text { n }\end{array}$ & $\begin{array}{c}42,3 \\
9\end{array}$ & \multirow{2}{*}{$\begin{array}{c}0,1 \\
3\end{array}$} & \multirow{2}{*}{$\begin{array}{c}1,9 \\
9\end{array}$} & \multirow{2}{*}{$\begin{array}{l}\text { Ho } \\
\text { diter } \\
\text { ima }\end{array}$} \\
\hline 2 & $\begin{array}{l}\text { Pretes } \\
\text { Kelas } \\
\text { Kontrol }\end{array}$ & $\begin{array}{l}42,1 \\
6\end{array}$ & & & \\
\hline
\end{tabular}

Tabel 4. Uji Hipotesis Data Pretes

Berdasarkan Tabel 4 di atas, perhitungan uji kesamaan nilai ratarata pretes kelas eksperimen dan kelas kontrol untuk $\alpha=0,05, t_{\text {hitung }}<t_{\text {tabel }}$ yaitu $0,13<1,9$, sehingga dapat disimpulkan bahwa kemampuan awal siswa pada kelas eksperimen sama dengan kemampuan awal siswa pada kelas kontrol.

Tabel 5. Uji Normalitas Data Postes

\begin{tabular}{|l|l|l|l|l|}
\hline No & Data & $\begin{array}{l}\text { Lhitun } \\
\mathrm{g}\end{array}$ & $\begin{array}{l}\text { Ltabe } \\
\text { (1) }\end{array}$ & $\begin{array}{l}\text { Kesimpul } \\
\text { an }\end{array}$ \\
\hline 1 & $\begin{array}{l}\text { Postes } \\
\text { Kelas }\end{array}$ & $\begin{array}{l}4,09 \\
\text { Eksperim } \\
\text { en }\end{array}$ & & \\
\hline 2 & $\begin{array}{l}\text { Postes } \\
\text { Kelas } \\
\text { Kontrol }\end{array}$ & 0,09 & 3 & Normal \\
& 1 & & \\
\hline
\end{tabular}

Tabel 5 menunjukkan bahwa Lhitung $<\mathrm{L}_{\text {tabel }}$ baik kelas eksperimen 
dan kelas kontrol dengan $\alpha=0,05$, sehingga dapat disimpulkan bahwa data berdistribusi normal.

Tabel6.Uji Homogenitas Data Postes

\begin{tabular}{|l|l|l|l|l|l|}
\hline No & \multicolumn{1}{|c|}{ Data } & $\begin{array}{l}\text { Vari } \\
\text { ans }\end{array}$ & $\begin{array}{c}\text { Fitu } \\
\text { ng }\end{array}$ & $\begin{array}{c}\text { Ftabe } \\
\mathrm{l}\end{array}$ & $\begin{array}{c}\text { Kesi } \\
\text { mpul } \\
\text { an }\end{array}$ \\
\hline 1 & $\begin{array}{l}\text { Postes } \\
\text { Kelas } \\
\text { Eksperim } \\
\text { en }\end{array}$ & $\begin{array}{l}66,8 \\
0\end{array}$ & $\begin{array}{l}1,6 \\
4\end{array}$ & $\begin{array}{l}1,6 \\
7\end{array}$ & $\begin{array}{l}\text { Hom } \\
\text { ogen }\end{array}$ \\
\hline 2 & $\begin{array}{l}\text { Postes } \\
\text { Kelas } \\
\text { Kontrol }\end{array}$ & 40,6 & 4 & & \\
\hline
\end{tabular}

Tabel 6. menunjukkan bahwa $\mathrm{F}_{\text {hitung }}<\mathrm{F}_{\text {tabel }}$ yaitu $1,64<1,67$ dengan $\mathrm{a}$ $=0,10$, maka dapat disimpulkan bahwa data postes kelas eksperimen memiliki varians yang sama dengan kelas kontrol (homogen).

Tabel 7. Uji Hipotesis Data Postes

\begin{tabular}{|c|l|l|l|l|l|}
\hline $\begin{array}{c}\text { N } \\
\mathrm{o}\end{array}$ & \multicolumn{1}{|c|}{ Data } & $\begin{array}{c}\text { Nilai } \\
\text { Rata- } \\
\text { rata }\end{array}$ & $\begin{array}{c}\text { thitun } \\
\mathrm{g}\end{array}$ & $\begin{array}{c}\mathrm{t}_{\text {tab }} \\
\text { el }\end{array}$ & $\begin{array}{c}\text { Kesimp } \\
\text { ulan }\end{array}$ \\
\hline 1 & $\begin{array}{l}\text { Postes } \\
\text { Kelas } \\
\text { Eksperime } \\
\mathrm{n}\end{array}$ & $\begin{array}{l}75,7 \\
6\end{array}$ & 2,6 & 1,6 & $\begin{array}{c}\mathrm{H}_{\mathrm{a}} \\
\text { diterim } \\
\mathrm{a}\end{array}$ \\
\cline { 1 - 3 } 2 & $\begin{array}{l}\text { Postes } \\
\text { Kelas } \\
\text { Kontrol }\end{array}$ & $\begin{array}{l}70,5 \\
3\end{array}$ & & & \\
\hline
\end{tabular}

Berdasarkan tabel 7, kelas eksperimen yang diajarkan dengan model pembelajaran problem based learning menggunakan peta konsep memperoleh nilai rata-rata hasil belajar sebesar 75,76 dan kelas kontrol yang diajarkan dengan model konvensional memperoleh hasil belajar dengan rata-rata hasil belajar sebesar 70,53. Data di atas menunjukkan bahwa thitung $>$ tabelyaitu( $2,6>1,6)$, sehingga dapat disimpulkan bahwa ada pengaruh model pembelajaran problem besad learning menggunakan peta konsep terhadap hasil belajar siswa pada materi fluida statis di kelas XI semester II SMA Negeri 1 Tanjung Morawa T.P 2014/2015.
Aktivitas siswa dikelas eksperimen mengalami peningkatan selama pembelajaran dengan menggunakan model problem based learning menggunakan peta konsep yaitu nilai rata-rata aktivitas belajar siswa pada pertemuan I yaitu, 56,46\%, pertemuan II rata-rata $74,94 \%$, serta pertemuan III $86,95 \%$. Hal ini menunjukkan bahwa modelproblem based learning menggunakan peta konsep tidak hanya meningkatkan hasil belajar siswa saja, tetapi juga dapat meningkatkan aktivitas siswa.

\section{Pembahasan}

Hasil penelitian menunjukkan bahwa ada pengaruh penerapan model problem based learning menggunakan peta konsepterhadap hasil belajar siswa pada materi fluida statis di kelas XI semester II SMA Negeri 1 Tanjung Morawa T.P.2014/2015. Hal ini diperkuat dengan adanya perbedaan hasil belajar siswa yang dapat dilihat dari hasil postes kelas eksperimen yang memperoleh rata-rata nilai 75,76 sedangkan hasil postes di kelas kontrol memperoleh rata-rata 70,53.

$\begin{array}{ccr}\text { Kelas } & \begin{array}{c}\text { eksperimen } \\ \text { perlakuan }\end{array} & \begin{array}{r}\text { yang } \\ \text { dengan }\end{array}\end{array}$
menerapkan model problem based learning menggunakan peta konsep memperoleh hasil berbeda dengan kelas kontrol yang diajarkan dengan model pembelajaran konvensional yang sebelumnya telah diketahui memiliki kesamaan kemampuan awalnya yaitu 42,39 untuk kelas eksperimen dan 42,15 untuk kelas kontrol dengan thitung $<\quad$ tabel yaitu $0,13<1,99$. Kemampuan akhir siswa dapat dilihat dengan memberikan postes terhadap kedua kelas. Hasil belajar yang diperoleh adalah nilai rata-rata hasil belajar untuk kelas eksperimen adalah 75,76 sedangkan untuk kelas kontrol adalah 70,53 dengan thitung $>t_{\text {tabel }} 2,6>$ 1,6. Berdasarkan data tersebut, dapat disimpulkan bahwa ada pengaruh model pembelajaran berbasis masalah terhadap hasil belajar siswa pada materi fluida statis di kelas XI SMA 
Negeri 1 Tanjung Morawa TP.2014/1015.

Modelproblem based learning memberikan kesempatan pada siswa bereksplorasi mengumpulkan data dan menganalisis data untuk memecahkan masalah, sehinnga siswa mampu untuk berpikir kritis dan logis menemukan alternatif pemecahan masalah, dengan menggunakan media peta konsep yang menjelaskan materi pembelajaran dari pusat permasalahan yang terjadi dalam lingkungan siswa. Maka siswa dalam hal ini aktif dan antusias untuk bekerja sama dengan teman satu kelompok dalam menyelesaikan masalah yang diberikan oleh peneliti.

Siswa juga tertarik dan aktif saat berdiskusi dan mengeluarkan pendapat yang berbeda saat diadakan diskusi kelompok. Tahap oreantasi siswa pada masalah (pertama), peneliti memotivasi siswa dengan memberikan tujuan pembelajaran yang akan di capai oleh siswa dan pada tahap ini peneliti memberikan masalah kepada siswa dengan memberikan pertanyaan sederhana yang berbeda dalam kehidupan sehari-hari siswa. Tahap mengorganisasi siswa untuk belajar (kedua), peneliti memberikan materi pelajaran kemudian membetuk kelompok-kelompok belajar dan melakukan percobaan (eksperimen). Tahap penyelidikan individual maupun kelompok (ketiga), peneliti membimbing setiap siswa untuk mengumpulkan informasi untuk memecahkan masalah, dan melakukan percobaan (eksperimen) sekal lagi. Tahap mengembangkan dan mempresentasikan artefak dan exbihit (keempat), peneliti membantu setiap kelompok menyelesaikan dan menjawab semua permasalahan yang ada, serta mempresentasikan hasil diskusi kelompok yang sudah disiapkan, kemudian kelompok yang lain memberikan pendapat atau masukan. Tahap menganalisis dan mengevaluasi proses mengatasi masalah (kelima), peneliti membantu siswa dalam mengkaji ulang pemecahan masalah sesuai dengan tujuan pembelajaran dan memberikan penguatan pada pemecahan masalah tersebut dan pada tahap ini penelitimembuat tes evaluasi untuk mengetahui pemahaman siswa.

Adapun beberapa kelebihan dari model pembelajaran problem based learning adalah : 1) meningkatkan motivasi belajar karena siswa dilibatkan secara aktifdalam proses pembelajaran, 2) siswa dilatih mengaitkan permasalahan yang dipelajari dengan kehidupan seharihari sehingga siswa dituntut untuk belajar menemukan, 3) siswa lebih terampil dalam berfikir tinggi, seperti menganalisis, memecahkan masalah yang terjadi dalam kehidupan seharihari, menemukan, mengevaluasi, bekerja sama, menunjukkan komunikasi antar sesama teman.

Penggunaan model problem based learning dapat meningkatkan hasil belajar, tetapi peneliti juga mengakui bahwa tetap masih ada siswa yang belum mencapai KKM. Hal ini di karenakan selama pembel;ajaran masih ada kendala yang di hadapi dalam penelitian yaitu, 1) ketika menentukan masalah yang autentik untuk dipecahkan saat proses pembelajaran berlangsung, 2) pelaksanaan semua fase-fase dalam model pembelajaran problem based learning kurang efektif karena keterbatasan peneliti dalam mengalokasi waktu sesuai RPP, 3) kurangnya pengalaman peneliti dalam mengelola kelas sehingga kondisi siswa yang ribut menyebabkan peneliti menjadi kurang efesien, serta peneliti belum berpengalaman mengajar menggunakan model pembelajaran problem based learning.

\section{KESIMPULAN DAN SARAN \\ Kesimpulan}

Hasil belajar Fisika pada meteri fuida statis kelas XI semester II di SMA Negeri 1 Tanjung Morawa T.P. 2014/2015 sebagai berikut:Ada 
pengaruh yang signifikan dari model problem based learning menggunakan peta konsep terhadap hasil belajar siswa pada materi fluida statis di kelas XI semester II SMA Negeri 1 Tanjung Morawa T.P. 2014/2015. Hal ini dapat dilihat berdasarkan perhitungan hasil belajar melalui uji $t$ pada taraf signifikansi $a=0,05$. Hasil belajar siswa dengan menggunakan model problem based learning menggunakan peta konsep terhadap hasil belajar siswa pada materi fluida statis di kelas XI semester II SMA Negeri 1 Tanjung Morawa T.P. 2014/2015, diperoleh nilai rata-rata pretes sebesar 42,39 dan nilai rata-rata postes sebesar 75,76. Hasil belajar siswa dengan menggunakan model pembelajaran konvensional pada materi fluida statis di kelas XI semester II SMA Negeri 1 Tanjung Morawa T.P 2014/2015, diperoleh nilai rata-rata pretes sebesar 42,16 dan nilai rata-rata postes sebesar 70,53. Aktivitas belajar siswa meningkat selama mengikuti pembelajaran dengan menggunakan problem based laerning menggunakan peta konsep.

Saran

Berdasarkan hasil dan kesimpulan dalam penelitian ini, maka sebagai tindak lanjut dari peneliti ini disarankan bagi peneliti selanjutnya hendaknya lebih memahami bagaimana mengambil masalah seperti apa yang layak dijadikan masalah untuk dipecahkan oleh siswa yang akan diberi perlakuan, lebih berusaha untuk memotivasi siswa terhadap masalah dalam kehidupan sehari-hari, serta melakukan pembimbingan yang penuh pada saat melakukan praktkum.

\section{DAFTAR PUSTAKA}

Arends, R. I., (2008), Learning to Teach Edisi Ketujuh, Pustaka Pelajar, Yogyakarta.

Arikunto, S., (2010), Prosedur Penelitian, PT Rineka Cipta, Jakarta.

Arsyad, A., (2009), Media Pembelajaran, Rajawali Pers. Jakarta

Muktar., Firdaus .M., Mulyono., (2013), Jurnal Penelitian Bidang Pendidikan, Pengembangan Pembelajaran matematika Berbasis Masalah Untuk Meningkatkan Kemampuan Penalaran dan Pemahaman Konsep Siswa SMA, Volume 19 (2); 79-86, 2013.

Panggabean, J. H., Jurnal Penelitian Bidang Pendidikan, Pengaruh Model Pembelajaran Kooperatif Tipe Jigsaw Terhadap Hasil Belajar Fisika Pokok Bahasan Kinematika Gerak Lurus DI Kelas 1 MAN 1 Medan, Volume 16 (1)-17,2010.

Trianto., (2011), Mendesain Model Pembelajaran Inovatif Progresif, Kencana, Jakarta.

Turnip, M. B., (2010), Jurnal Penelitian Bidang Pendidikan, Pengaruh Pete Pikiran (Mind Map) Terhadap hasil Belajar Fisika Siswa Pada Materi Pokok tata Surya Di Kelas VII Semester II SMPN 1 Percut Sei Tuan.Volume 16 (1): 43-49,2010 